\title{
PROFESOR ANDRZEJ MATCZAK
}

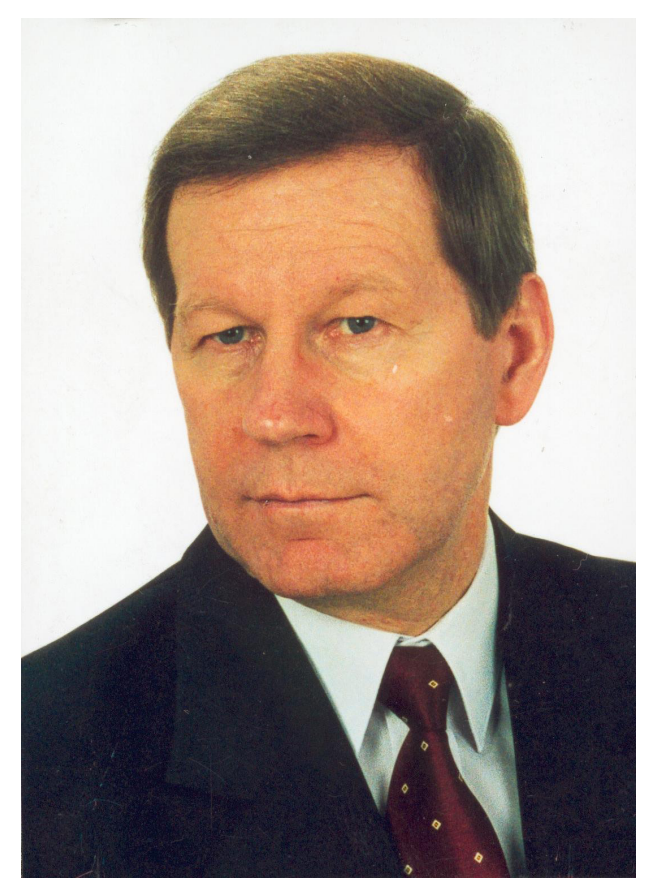

Profesor Andrzej Matczak kieruje Zakładem Geografii Hotelarstwa będącym częścią Instytutu Geografii Miast i Turyzmu na Wydziale Nauk Geograficznych Uniwersytetu Łódzkiego. Urodził się 19 maja $1950 \mathrm{r}$ w Uniejowie. Z Uniwersytetem Łódzkim związany jest od 1968 r., kiedy na ówczesnym Wydziale Biologii i Nauk o Ziemi rozpoczął studia geograficzne. Pracę magisterską pod kierunkiem prof. dr. hab. Tadeusza Olszewskiego, zatytułowaną Zmiany form użytkowania ziemi na obszarach wiejskich tódzkiej aglomeracji miejskiej w latach 1963-1973 (w świetle spisów rolnych GUS). Część pótnocna, obronił w $1973 \mathrm{r}$. Karierę zawodową początkowo związał z Wojewódzką Pracownią Planów Regionalnych w Łodzi, ale już w 1974 r. przeniósł się do Instytutu Geografii Uniwersytetu Łódzkiego, do Zakładu Geografii Ekonomicznej, którego kierownikiem był prof. dr. hab. Ludwik Straszewicz. W 1982 r. obronił rozprawę doktorską pt. Funkcja wypoczynkowa strefy podmiejskiej Łodzi, przygotowaną pod opieką prof. dr. hab. Stanisława Liszewskiego. Stopień doktora habilitowanego uzyskał w 1992 r. na podstawie pracy pt. Model badań ruchu turystycznego. Studium metodologiczne. Tytuł naukowy profesora otrzymał w $2002 \mathrm{r}$.

Andrzej Matczak w 1995 r. został Dyrektorem Instytutu Geografii Ekonomicznej i Organizacji Przestrzeni i jednocześnie Kierownikiem Zakładu Metod Ilościowych w Geografii w Katedrze Geografii Miast i Turyzmu kierowanej przez prof. dr. hab. Stanisława Liszewskiego. W latach 1996-1999 pełnił funkcję prodziekana Wydziału Biologii i Nauk o Ziemi Uniwersytetu Łódzkiego. W 2001 r. w Uniwersytecie Łódzkim powołano Wydział Nauk Geograficznych. W wyniku reorganizacji jednostek geograficznych $\mathrm{w}$ strukturach nowego Wydziału prof. Andrzej Matczak objął stanowisko Kierownika Zakładu Geografii Hotelarstwa, początkowo wchodzącego w skład Katedry, a od 2007 r. - Instytutu Geografii Miast i Turyzmu. Na etacie profesora 
nadzwyczajnego Uniwersytetu Łódzkiego Andrzej Matczak pracował od 1997 r. W 2004 r. został mianowany na stanowisko profesora zwyczajnego. W swojej karierze współpracował również z innymi uczelniami - Wyższą Szkołą Turystyki i Rekreacji w Warszawie (w latach 1998-2000), Instytutem Geografii Uniwersytetu Kazimierza Wielkiego w Bydgoszczy (20012008), Wyższą Szkołą Humanistyczno-Ekonomiczną w Łodzi (2003-2005) i Wydziałem Turystyki i Geografii Wyższej Szkoły Gospodarki w Bydgoszczy (2008-2012).

Profesor Andrzej Matczak związany był z różnymi instytucjami naukowymi w Łodzi i w Polsce. Od 1995 r. jest członkiem Łódzkiego Towarzystwa Naukowego. Aktywnie działa również w Oddziale Łódzkim Polskiego Towarzystwa Geograficznego. W latach 1999-2003 pełnił funkcję sekretarza Komitetu Nauk Geograficznych Polskiej Akademii Nauk, a w kadencji 2016-2020 działał jako członek Komitetu. Od 1992 r. przez wiele lat był członkiem redakcji wydawnictwa naukowo-dydaktycznego Uniwersytetu Łódzkiego "Acta Universitatis Lodziensis. Folia Geographica Socio-Oeconomica”, a w latach 1993-1994 pełnił funkcję jej sekretarza. Od 2000 r. jest członkiem Rady Redakcyjnej czasopisma „Turyzm/Tourism”. Uczestniczył w licznych wizytach studyjnych i stażach naukowych, zarówno w Polsce, jak i poza jej granicami, m.in. w: Lipsku (1975), Warszawie (1979-1980), Giessen (1983), Berlinie (1985), Pradze (1989, 1997), Sofii (1990), Tbilisi (1990), Aix-en-Provence (1991), Preszowie (1994), Bratysławie (1999). W 1994 r. otrzymał Złotą Odznakę Uniwersytetu Łódzkiego. W 2001 r. został odznaczony medalem Uniwersytet Łódzki w Służbie Społeczeństwu i Nauce, a w 2002 r. - Srebrnym Krzyżem Zasługi. W 2019 r. Wydział Geografii i Studiów Regionalnych Uniwersytetu Warszawskiego wyróżnił prof. Andrzeja Matczaka Medalem im. Jerzego Kondrackiego. Dnia 7 stycznia 2008 r., podczas uroczystej sesji rady miejskiej, podjęto uchwałę o nadaniu prof. Matczakowi tytułu Honorowego Obywatela Miasta Uniejowa.

Działalność naukowo-badawcza prof. Andrzeja Matczaka skoncentrowana jest wokół dwóch subdyscyplin geograficznych: geografii turyzmu i geografii osadnictwa. Wskazać można następujące, najważniejsze problemy badawcze z zakresu geografii turyzmu poruszane przez Profesora: metodyka badań ruchu turystycznego; przemiany funkcji wypoczynkowej i turystycznej w strefie podmiejskiej; lokalizacja i funkcjonowanie przedsiębiorstw turystycznych, w szczególności hoteli. Uzupełniający charakter miały badania dotyczące funkcji turystycznej miast oraz analizy geograficznej rynku turystycznego. Z kolei dorobek Profesora w zakresie geografii osadnictwa obejmuje takie zagadnienia, jak: metodyka badania przestrzennego oddziaływania miast poprzez analizę związków miast z ich zapleczem, struktura funkcjonalna i funkcjonalno-przestrzenna miast, przekształcenia funkcjonalno-przestrzenne strefy podmiejskiej.

Jednym z najważniejszych osiągnięć prof. Andrzeja Matczaka było wypracowanie metodyki badań ruchu turystycznego. Model badań ruchu turystycznego został przez niego szczegółowo opisany w opublikowanej rozprawie habilitacyjnej. Praca była próbą oceny wcześniejszych, jak również wskazaniem przyszłych kierunków badań nad ruchem turystycznym. Co więcej, prof. Andrzej Matczak podjął próbę dostosowania metodyki badania ruchu turystycznego do konkretnych warunków empirycznych obszarów chronionych (Matczak, 2002c), nadmorskich (Matczak, 2005a, 2005c, 2009a) i zurbanizowanych (Matczak, 2012). Rozwój ruchu turystycznego prof. Andrzej Matczak wiąże ściśle z zagadnieniem percepcji przestrzeni turystycznej (Matczak, 1993a, 1994a, 1996a).

Podjęta przez prof. Andrzeja Matczaka dyskusja dotycząca funkcji wypoczynkowej i turystycznej terenów podmiejskich była wynikiem wieloletnich prac empirycznych, które swoim zasięgiem przestrzennym obejmowały przede wszystkim obszar funkcjonalny Łodzi. Profesor Andrzej Matczak podją początkowo próbę opisania funkcji turystycznej na terenach podmiejskich (Matczak, 1984b, 1986a, 1986b, 1986c, 1986d, 1987a, 1987b, 1991a, 1991b, 1991c, 1994b, 1996b). Następnie skoncentrował się na analizie procesów kolonizacji turystycznej strefy podmiejskiej (Matczak, 1995a, 1995b). Swoje ostatnie prace dotyczące omawianej problematyki poświęcił natomiast presji funkcji mieszkaniowej na terenach letniskowych w strefie podmiejskiej (Matczak, 2005b, 2009b, 2016a). Podsumowaniem dorobku prof. Andrzeja Matczaka w zakresie badań nad funkcją turystyczną jest jego przeglądowy artykuł pt. Funkcja turystyczna w badaniach łódzkiego ośrodka geografii turyzmu (Matczak, 2015).

Profesor Andrzej Matczak zapoczątkował w ośrodku łódzkim dyskusję na temat problemów lokalizacji hoteli, jak również metodyki badań nad tym zagadnieniem (Matczak, 2004b; Matczak, Szkup, 2020). Najważniejsze prace były pokłosiem wieloletnich studiów poświęconych lokalizacji obiektów świadczących usługi hotelowe w trzech ośrodkach miejskich: Łodzi (Matczak, 1993b, 1998d, 2002b, 2004a, 2011c, 2016b, 2018, 2020), Bydgoszczy (Matczak, Grabiszewski, 2010) i Budapeszcie (Matczak, Napierała, 2004, 2014), jak również w skali ogólnopolskiej (Matczak, 2017). Wspomniane prace dotyczyły przede wszystkim rozwoju przedsiębiorstw hotelarskich i ich polityki lokalizacyjnej w okresie transformacji ustrojowej w krajach Europy Środkowo-Wschodniej. Wyniki pozwoliły potwierdzić, że rozwój sektora hotelarskiego współzależy od rozwoju ogólnogospodarczego regionów w procesie transformacji.

Badania prof. Andrzeja Matczaka z zakresu geografii osadnictwa dotyczyły przede wszystkim delimitacji 
regionów miejskich na podstawie analizy ruchów migracyjnych, jak również przekształceń funkcjonalno-przestrzennych badanych regionów miejskich. Były to $\mathrm{w}$ zdecydowanej większości studia przypadków małych i średnich miast w Polsce: Brodnicy (Matczak, Szymańska, 1998; Szymańska, Matczak, 1996, 1998), Łasku (Matczak, 2000b; Matczak, Michalski, 1999), Łęczycy (Matczak, 2002a), Prudnika (Matczak, 1984a), Sępólna Krajeńskiego (Matczak, 2011b), Sieradza (Matczak, 1998c; Matczak, Michalski, 1981) i Zduńskiej Woli (Matczak, 1998a, 1998b). Profesor Andrzej Matczak opublikował również wiele studiów porównawczych odnoszących się do wskazanej problematyki (Matczak, 1992, 2000a, 2011a; Matczak, Szymańska, 2000a, $2000 b)$. Wyniki badań podjętych przez prof. Andrzeja Matczaka przyczyniły się do potwierdzenia specyfiki procesu urbanizacji regionów funkcjonalnych małych i średnich miast, w którym kluczowe znaczenie miało odejście od specjalizacji na rzecz dominacji standardowych usług. Opisane procesy urbanizacyjne właściwe dla krajów, które przeszły transformację ustrojową były całkowicie różne od specyfiki urbanizacji krajów zachodnioeuropejskich (Szymańska, Matczak, 2002).

Profesor Andrzej Matczak opublikował dotąd łącznie 158 prac naukowych, z czego zdecydowaną większość stanowią własne lub współautorskie artykuły lub rozdziały w monografiach, prezentujące osiągnięcia badań empirycznych. Wielokrotnie angażowany był jako recenzent $\mathrm{w}$ postępowaniach doktorskich (17), habilitacyjnych (6) i profesorskich (4). Wypromował łącznie 8 doktorów: Romana Szkupa, Ewę Szafrańską, Krzysztofa Parzycha, Rafała Gotowskiego, Alicję Gonię, Tomasza Napierałę, Andrzeja Płońskiego i Monikę Kozłowską-Adamczak. Jest promotorem 297 prac magisterskich obronionych na Uniwersytecie Łódzkim, 30 - na Uniwersytecie Kazimierza Wielkiego w Bydgoszczy, i 17 - w Wyższej Szkole Gospodarki w Bydgoszczy. Pod opieką prof. Andrzeja Matczaka powstało 50 prac licencjackich obronionych w Wyższej Szkole Turystyki i Rekreacji w Warszawie i 51 przygotowanych w Wyższej Szkole Humanistyczno-Ekonomicznej w Łodzi.

\section{Tomasz Napierała}

Redakcja czasopisma „Turyzm/Tourism”, pracownicy Instytutu Geografii Miast i Turyzmu oraz cała społeczność Wydziału Nauk Geograficznych Uniwersytetu Łódzkiego składają Panu Profesorowi Andrzejowi Matczakowi gratulacje z okazji Jubileuszu 70. urodzin oraz serdeczne życzenia zdrowia, wielu radości, wszelkiej pomyślności, a także kolejnych sukcesów w działalności naukowej. Panie Profesorze, ad multos annos!

\section{BIBLIOGRAFIA}

Matczak, A. (1984a). Próba określenia zasięgu oddziaływania Prudnika na podstawie danych o przewozach towarowych. Acta Universitatin Lodzinensis. Folia Geographica, 3, 87-97.

Matczak, A. (1984b). Próba wykorzystania analizy morfologicznej do określenia funkcji wypoczynkowej osiedli w strefie podmiejskiej Łodzi. Problemy Turystyki, 2, 93-97.

Matczak, A. (1986a). Budownictwo letniskowe w strefie podmiejskiej Łodzi. Acta Universitatin Lodzinensis. Folia Geographica, 7, 137-166.

Matczak, A. (1986b). Dostępność komunikacyjna terenów wypoczynkowych w strefie podmiejskiej Łodzi. Przeglad Ekonomiczno-Społeczny m. Łodzi, 9, 113-125.

Matczak, A. (1986c). La fonction recreative de la zone suburbaine de la ville de Łódź. W: F. Vetter (red.), Grosstadttourismus - Tourisme des grandes villes (s. 304-315). Berlin: Union Géographique Internationale, Commission de Géographie du Tourisme et des Loisirs.

Matczak, A. (1986d). Przyrodnicze podstawy organizacji wypoczynku w strefie podmiejskiej Łodzi. Acta Universitatis Lodziensis. Turyzm, 2, 25-45.

Matczak, A. (1987a). Próba określenia funkcji wypoczynkowej osiedli podmiejskich na przykładzie Kolumny. Acta Universitatis Lodziensis. Turyzm, 3, 55-85.

Matczak, A. (1987b). Ruch wypoczynkowy w strefie podmiejskiej Łodzi. Acta Universitatin Lodzinensis. Folia Geographica, 8, 21-39.

Matczak, A. (1991a). Funkcja wypoczynkowa osiedli podłódzkich w świetle badań użytkowania ziemi. Acta Universitatis Lodzinensis. Folia Geographica, 13, 129-140.

Matczak, A. (1991b). Methods of studying the recreational function of suburban settlements. Zeszyty Naukowe Uniwersytetu Jagiellońskiego. Prace Geograficzne, 86, 109-122.

Matczak, A. (1991c). Przemiany przestrzenne wsi położonych w strefie podmiejskiej Łodzi na przykładzie rejonu Grotnik. Acta Universitatin Lodzinensis. Folia Geographica, 14, 33-46.

Matczak, A. (1992). Zmiany w strukturze funkcjonalnej miast Polski w latach 1973-1983. Acta Universitatin Lodzinensis. Folia Geographica, 17, 9-25.

Matczak, A. (1993a). Percepcja przestrzeni turystycznej Polski przez młodzież licealną Łodzi. Turyzm, 3 (2), 61-70.

Matczak, A. (1993b). Turystyczna baza noclegowa Łodzi i jej wykorzystanie w latach 1979-1990. Kronika m. Łodzi, 2, 51-67.

Matczak, A. (1994a). Percepcja przestrzeni turystycznej Polski przez zamiejscową młodzież akademicką studiującą w Łodzi. Turyzm, 4 (1), 23-33.

Matczak, A. (1994b). Turystyka i wypoczynek jako czynnik integracji i rozwoju regionu łódzkiego. W: A. Matczak (red.), Studium wiedzy o regionie łódzkim. Wybrane problemy (s. 161-188). Łódź: Łódzkie Towarzystwo Naukowe.

Matczak, A. (1995a). Kolonizacja turystyczna obszarów wiejskich w strefie podmiejskiej Łodzi. W: A. Kowalczyk (red.), Zmiany w przestrzeni geograficznej w warunkach transformacji społeczno-ekonomicznej (na przykładzie obszarów wiejskich) (s. 49-59). Warszawa: Wydział Geografii i Studiów Regionalnych Uniwersytetu Warszawskiego.

Matczak, A. (1995b). Kolonizacja turystyczna strefy podmiejskiej Łodzi. Kronika m. Łodzi, 1, 108-119.

Matczak, A. (1996a). Percepcja regionalnej przestrzeni turystycznej przez uczniów szkół licealnych Łodzi. Turyzm, 6 (1), 63-75.

Matczak, A. (1996b). Turystyka i wypoczynek w łódzkim regionie miejskim. W: W. Michalski (red.), Transformacja społeczno-gospodarcza Łodzi na tle regionu (s. 99-109). Łódź: Centralny 
Urząd Planowania - Biuro Planowania Regionalnego w Łodzi, Polskie Towarzystwo Geograficzne - Oddział w Łodzi.

Matczak, A. (1998a). Delimitacja granic regionu miejskiego Zduńskiej Woli na podstawie danych o migracjach stałych. W: D. Szymańska (red.), Ruchliwość przestrzenna ludności w okresie przemian ustrojowych (s. 291-312). Toruń: Wydawnictwo Uniwersytetu Mikołaja Kopernika w Toruniu.

Matczak, A. (1998b). Delimitation of borders of the Zduńska Wola urban area using data on permanent migrations. Polish Population Review, 13, 191-210.

Matczak, A. (1998c). Migracje jako element delimitacji regionu społeczno-ekonomicznego. Przykład Sieradza. Acta Universitatis Wratislaviensis. Studia Geograficzne, 2048, 93-110.

Matczak, A. (1998d). Turystyczna baza noclegowa Łodzi i jej wykorzystanie w latach 1979-1997. Turyzm, 8 (2), 27-56.

Matczak, A. (2000a). Delimitacja granic regionów miejskich: Łasku, Zduńskiej Woli i Sieradza na podstawie danych o migracjach stałych. W: D. Szymańska (red.), Procesy i formy ruchliwości przestrzennej ludności w okresie przemian ustrojowych (s. 37-56). Toruń: Wydawnictwo Naukowe Uniwersytetu Mikołaja Kopernika.

Matczak, A. (2000b). Delimitacja regionu społeczno-ekonomicznego małego miasta powiatowego w Polsce na podstawie danych o migracjach stałych. Przykład Łasku. Urbanne a Krajinne Studie, 3, 248-261.

Matczak, A. (2002a). Delimitacja zaplecza społeczno-ekonomicznego Łęczycy. W: J. Słodczyk (red.), Przemiany bazy ekonomicznej i struktury przestrzennej miast (s. 205-218). Opole: Wydawnictwo Uniwersytetu Opolskiego.

Matczak, A. (2002b). Efektywność wykorzystania rejestrowanych obiektów noclegowych w Łodzi w latach 1979-2000. Turyzm/ Tourism, 12 (2), 65-78.

Matczak, A. (2002c). Metodyka badań ruchu turystycznego na obszarach chronionych. W: J. Partyka (red.), Użytkowanie turystyczne parków narodowych. Ruch turystyczny - zagospodarowanie - konflikty-zagrożenia (s. 17-22). Ojców: Ojcowski Park Narodowy.

Matczak, A. (2004a). Hotelarstwo polskie w okresie przemian. Przykład Łodzi. Zeszyty Naukowe WSG w Bydgoszczy. Seria Turystyka i Rekreacja, 1, 21-34.

Matczak, A. (2004b). Metodologia badań nad lokalizacją hoteli. W: A. Matczak (red.), Lokalizacja hoteli w krajowych metropoliach Europy Środkowo-Wschodniej (s. 11-43). Łódź: Łódzkie Towarzystwo Naukowe.

Matczak, A. (2005a). Badania przyjazdowego ruchu turystycznego w rejonie Ustki. W: E. Rydz (red.), Kształtowanie funkcji turystycznych w miejscowościach uzdrowiskowych (s. 265-284). Słupsk: Wydawnictwo Pomorskiej Akademii Pedagogicznej w Słupsku.

Matczak, A. (2005b). Rozwój podmiejskich osiedli letniskowych w świetle koncepcji cyklu życia obszaru turystycznego. Przykład podłódzkiego letniska w Wiśniowej Górze. W: B. Domański, S. Skiba (red.), Geografia i sacrum (s. 265-284). Kraków: Instytut Geografii i Gospodarki Przestrzennej UJ w Krakowie.

Matczak, A. (2005c). Turystyka w przestrzeni miejskiej Ustki - polskiego kurortu nadbałtyckiego. Turyzm/Tourism, 15 (1-2), 139-149.

Matczak, A. (2009a). Ruch turystyczny w Rowach w latach 1999-2007. W: R. Muszkieta, M. Napierała (red.), Wspomaganie rozwoju i edukacji człowieka poprzez turystyke, sport i rekreacje (s. 25-47). Bydgoszcz: Wydawnictwo WSG w Bydgoszczy.

Matczak, A. (2009b). Urbanizacja podmiejskich osiedli letniskowych. Przykład Wiśniowej Góry w strefie podmiejskiej Łodzi. Turyzm/Tourism, 19 (1-2), 67-72.
Matczak, A. (2011a). Changes in the functional struckture of the cities in the Lodz region in 1973-2007. W: A. Runge, A. Kuczabski (red.), Medium-sized towns of Central-Eastern Europe in the period of economic system transportation and social changes (s. 35-44). Kharkiv: Publishing House ADNDU.

Matczak, A. (2011b). Identyfikacja regionu społeczno-ekonomicznego małego miasta. Przykład Sępólno Krajeńskie. W: K. Marciniak, R. Sikora, D. Sokołowski (red.), Koncepcje i problemy badawcze geografii. Profesorowi Wiestawowi Maikowi w 70-lecie urodzin (s. 23-28). Bydgoszcz: Wydawnictwo WSG w Bydgoszczy.

Matczak, A. (2011c). Turystyczna baza noclegowa w Łodzi w latach 1979-2009. W: B. Włodarczyk (red.), Turystyka. Ksiegga jubileuszowa w 70. rocznice urodzin Profesora Stanistawa Liszewskiego (s. 287-296). Łódź: Wydawnictwo Uniwersytetu Łódzkiego.

Matczak, A. (2012). Koncepcja monitorowania ruchu turystycznego w dużym mieście. W: S. Sitek (red.), ",Stare i nowe" problemy badawcze geografii społeczno-ekonomicznej (s. 77-91). Sosnowiec: Polskie Towarzystwo Geograficzne, Oddział Katowicki, Uniwersytet Śląski, Wydział Nauk o Ziemi.

Matczak, A. (2015). Funkcja turystyczna w badaniach łódzkiego ośrodka geografii turyzmu. W: Z. Młynarczyk, A. Zajadacz (red.), Uwarunkowania i plany rozwoju turystyki. Tom XIV: Rozwój badań geograficznych nad turystyka (s. 101-116). Poznań: Uniwersytet im. Adama Mickiewicza w Poznaniu.

Matczak, A. (2016a). Urbanizacja podłódzkich osiedli letniskowych. Przykład Miasta-Lasu Kolumny. W: A. Zborowski (red.), Człowiek, społeczeństwo, przestrzeń (s. 105-121). MyczkowceKraków: Instytut Geografii i Gospodarki Przestrzennej UJ w Krakowie, Centrum Kultury Ekumenicznej.

Matczak, A. (2016b). Zmiany w wielkości i strukturze turystycznej bazy noclegowej Łodzi po 1989 r. W: D. Sokołowski, P. Tomczykowska (red.), Kreatywność w turystyce. Innowacyjne rozwiązania we współczesnej turystyce (s. 11-29). Toruń: Wydawnictwo Naukowe Uniwersytetu Mikołaja Kopernika.

Matczak, A. (2017). Zmiany w liczbie i pojemności hoteli w Polsce. Turyzm/Tourism, 27 (2), 77-87. DOI: https://doi. org/10.18778/0867-5856.27.2.07

Matczak, A. (2018). Zmiany w potencjale i wykorzystaniu hoteli łódzkich po 1989 r. W: S. Sitek (red.), "Stare i nowe" problemy badawcze geografii społeczno-ekonomicznej (s. 7-27). Sosnowiec: Polskie Towarzystwo Geograficzne, Oddział Katowicki, Uniwersytet Śląski, Wydział Nauk o Ziemi.

Matczak, A. (2020). Zmiany w wielkości i użytkowaniu hoteli w Łodzi. W: R. Szkup (red.), Turystyczna baza noclegowa województwa tódzkiego (s. 127-147). Łódź: Wydawnictwo Uniwersytetu Łódzkiego. DOI: https://doi.org/10.18778/8142-645-9.05

Matczak, A., Grabiszewski, M. (2010). Turystyczna baza noclegowa Bydgoszczy i jej wykorzystanie w latach 1979-2009. Zeszyty Naukowe WSG w Bydgoszczy. Seria Turystyka i Rekreacja, $15,105-131$.

Matczak, A., Michalski, W. (1981). Przepływy towarowe jako podstawa wyznaczania związków przestrzennych Sieradza. Acta Universitatin Lodzinensis. Folia Geographica, 1, 129-152.

Matczak, A., Michalski, W. (1999). Zmiany w zasięgu przestrzennym oddziaływania społeczno-ekonomicznego Łasku w okresie transformacji ustrojowej. W: A. Matczak (red.), Studia nad struktura funkcjonalno-przestrzenna miasta. Przykład Łasku (s. 77-98). Łódź: Wydawnictwo Uniwersytetu Łódzkiego.

Matczak, A., Napierała, T. (2004). Lokalizacja hoteli w Budapeszcie. W: A. Matczak (red.), Lokalizacja hoteli w krajowych metropoliach Europy Środkowo-Wschodniej (s. 83-100). Łódź: Łódzkie Towarzystwo Naukowe.

Matczak, A., Napierała, T. (2014). Zmiany w lokalizacji hoteli w Budapeszcie. W: G. Gołembski, A. Niezgoda (red.), Tu- 
rystyka wobec zmian wspótczesnego świata. Zmiany, bariery, innowacje (s. 127-139). Poznań: Wydawnictwo Uniwersytetu Ekonomicznego w Poznaniu.

Matczak, A., Szkup, R. (2020). Turystyczna baza noclegowa jako przedmiot analiz naukowych. W: R. Szkup (red.), Turystyczna baza noclegowa województwa łódzkiego (s. 9-37). Łódź: Wydawnictwo Uniwersytetu Łódzkiego. DOI: https:// doi.org/10.18778/8142-645-9.01

Matczak, A., Szymańska, D. (1998). Permanent migrations as a measure of town's impact (the Brodnica case). Polish Population Review, 13, 175-190.

Matczak, A., Szymańska, D. (2000a). Baza ekonomiczna małych miast powiatowych w świetle pomiarów bezpośrednich. Studium porównawcze Brodnicy i Łasku. W: J. Słodczyk (red.), Społeczne, gospodarcze i przestrzenne przeobrażenia miast (s. 95113). Opole: Wydawnictwo Uniwersytetu Opolskiego.
Matczak, A., Szymańska, D. (2000b). Identyfikacja i pomiar bazy ekonomicznej miasta na przykładzie Brodnicy i Łasku. Acta Universitatis Nicolai Copernici. Geografia, 104, 191-211.

Szymańska, D., Matczak, A. (1996). Ruch wędrówkowy ludności i jego zasięg oddziaływania na przykładzie miasta Brodnicy. W: J. Falkowski (red.), Wybrane problemy geografii społeczno-ekonomicznej i zagospodarowania przestrzennego (s. 177-187). Toruń: Wydawnictwo Uniwersytetu Mikołaja Kopernika w Toruniu.

Szymańska, D., Matczak, A. (1998). Region miejski Brodnicy w świetle migracji stałych. Acta Universitatis Wratislaviensis. Studia Geograficzne, 2048, 79-91.

Szymańska, D., Matczak, A. (2002). Urbanization in Poland: Tendencies and transformation. European Urban and Regional Studies, 9 (1), 39-46. DOI: https://doi. org/10.1177/096977640200900104 